\title{
Comparison of Methods to Reduce Sidewalk Damage from Tree Roots
}

\author{
E. Thomas Smiley
}

\begin{abstract}
Tree roots growing under sidewalks are known to crack or lift pavement often creating a tripping hazard for pedestrians. This experiment was conducted to determine the long-term effects of below- and alongside-pavement treatments on tree root development and sidewalk damage. London, U.K. plane trees (Platanus $\times$ acerifolia) were planted next to sidewalks at the Bartlett Tree Research Laboratory in Charlotte, North Carolina, U.S., in 1996. Treatments installed at the time of planting were: DeepRoot Universal Tree Root Barrier (UB18-2), vertical polyethylene sheet, gravel, Foamular ${ }^{\circledR} 150$ extruded polystyrene, and a structural soil. The sidewalks and soil beneath them were removed in 2006. Minimal sidewalk lifting or cracking was associated with the DeepRoot barrier, gravel, and foam treatments. Vertical root barriers and foam resulted in fewer and deeper roots under the pavement. Treatments had no impact on tree diameter growth.

Key Words. DeepRoot barriers; Foamular ${ }^{\circledR}$; infrastructure damage; root barriers; sidewalk lifting; structural soil; Styrofoam ${ }^{\circledR}$; tripping hazard.
\end{abstract}

Tree roots growing under sidewalks are known to cause cracking or lifting of the pavement (D'Amato et al. 2002; Costello and Jones 2003), which may create a tripping hazard for pedestrians. The cost of repairing this type of damage is in excess of $\$ 100$ million per year in the United States (McPherson and Peper 1995; McPherson 2000).

Vertical barriers have been tested to assess their ability to direct root growth to deeper levels in the soil, thus reducing damage to the sidewalk (Wagar and Barker 1983; Wagar 1985; Barker and Peper 1995; Gilman, 1996; Costello et al. 1997; Gilman 2006). These products tend to work better in welldrained soils than in poorly drained soils (Gilman 2006). There are also differences among root barriers in their degree of initial effectiveness (Smiley 2005; Gilman 2006). Root barriers do not tend to reduce the stability of trees planted near them and may actually increase stability by promoting deeper root development (Smiley et al. 2000).

Gravel applied under pavement during construction has also been shown to reduce root growth immediately below the pavement on well-drained sites (Kopinga 1994; Gilman 2006). This is the result of the large pores in gravel, which, when installed in a well-drained site, do not retain water or nutrients needed for root growth.

Structural soils are installed beneath pavement to allow for root growth while bearing the weight of the pavement and vehicles (Grabosky and Bassuk 1996; Smiley et al. 2006). These gravel/soil mixes allow for initial rapid root growth. The effect of this root growth on pavement longevity is not well documented. It is recommended that structural soils be installed in layers totaling at least $60 \mathrm{~cm}$ (24 in) deep. In practice, it is common to see installations of 10 to $15 \mathrm{~cm}$ (4 to 6 in) beneath pavement (pers. obs.).

Foamular $^{\circledR}$ (Owens Corning, Toledo, OH, U.S.) is an extruded polystyrene foam board similar to Styrofoam ${ }^{\circledR}$ (Dow Chemical Co., Midland, MI) commonly used for building insulation. Sheets of foam are installed on the perimeter of basements and under foundations to reduce heat loss. Polyurethane foam sprays have been used to reduce root damage to replacement sidewalks
(Costello and Jones 2003). The use of foam as a preventive under pavement treatment has not been documented.

The purpose of this experiment was to determine the longterm effects of below- and alongside-pavement treatments on the growth of tree roots and sidewalk damage.

\section{MATERIALS AND METHODS}

Two sections of sidewalk were installed at the Bartlett Tree Research Laboratory in Charlotte, North Carolina, with London plane trees (Platanus $\times$ acerifolia) planted closely alongside (Figure 1). Thirty London plane trees were planted in four rows in the native Cecil sandy clay loam (CeB2, thermic typic hapludults) on 2 February 1996. The trees were $4 \mathrm{~cm}$ (1.6 in) caliper and transplanted with a tree spade on $6 \mathrm{~m}(19.8 \mathrm{ft})$ spacing. Tree trunks were centered $50 \mathrm{~cm}$ ( $20 \mathrm{in}$ ) from the edge of the sidewalk pavement.

To install the sidewalks, soil was removed to a depth of $10 \mathrm{~cm}$ (4 in) from two areas measuring $1.2 \mathrm{~m}(3.96 \mathrm{ft})$ wide by $45 \mathrm{~m}$ (148.5 ft) long. In areas to receive underpavement treatments, an additional $10 \mathrm{~cm}$ (4 in) of soil was removed. Underpavement treatments were installed before pouring the concrete, whereas the vertical barriers were installed next to the edge of the pavement immediately after paving. The top edge of all vertical barriers were installed above grade.

Treatments were as follows:

1) DeepRoot Tree Root Universal Barrier (UB 18-2; DeepRoot Partners, San Francisco CA)—an injection-molded copolymer polypropylene panel that is $2.032 \mathrm{~mm}(0.081$ in) thick by $45 \mathrm{~cm}$ (18 in). Panels were installed vertically within $3 \mathrm{~cm}$ (1.2 in) of the edge of the pavement.

2) Polyethylene sheet (Poly sheet) $-0.15 \mathrm{~mm}(0.01 \mathrm{in})$ thick by $45 \mathrm{~cm}$ (18 in) black polyethylene sheet was installed vertically within $3 \mathrm{~cm}$ (1.2 in) of the edge of the pavement.

3) Gravel-2.5 to $3.75 \mathrm{~cm}$ (1 to $1.5 \mathrm{in})$ diameter washed, crushed gravel was installed in a $10 \mathrm{~cm}$ (4 in) horizontal layer beneath the pavement. 

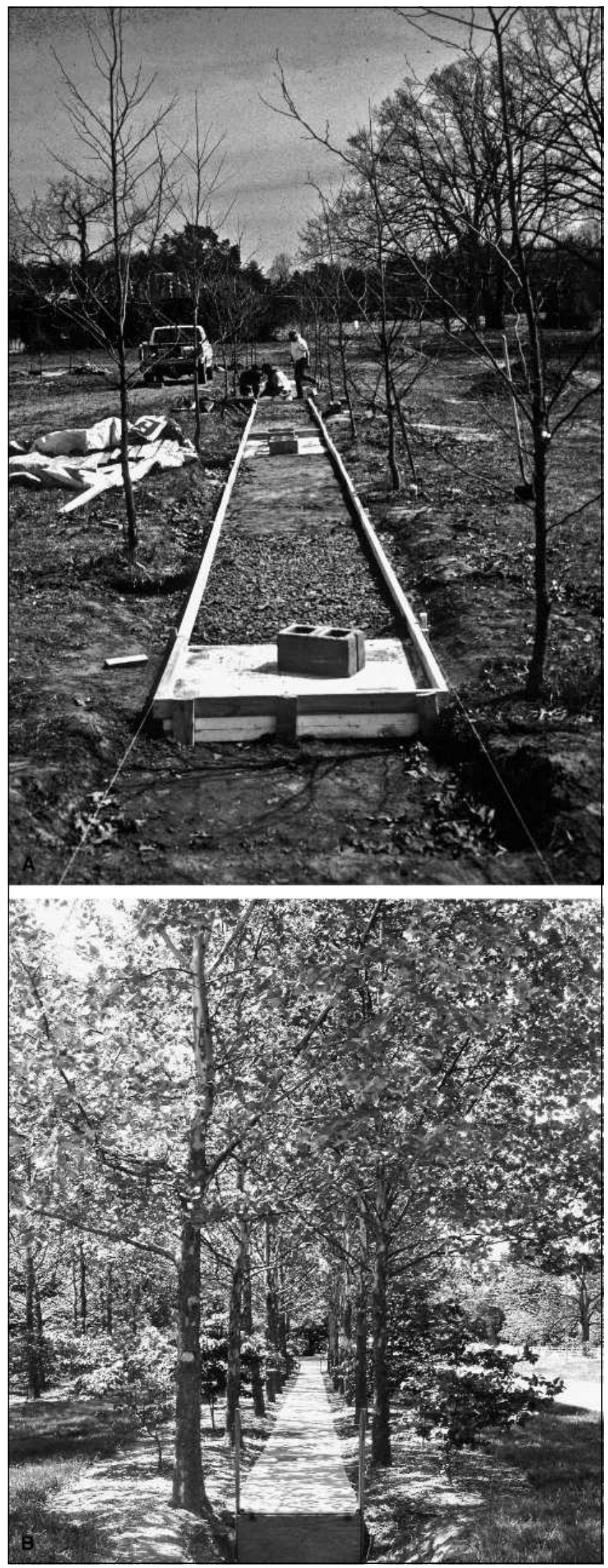

Figure 1. Sidewalk installation (1996, top) and a portion of the plot 10 years later (bottom).
4) Foamular $^{\circledR} 150$ extruded polystyrene (Foam) - two $5 \mathrm{~cm}$ ( 2 in) thick sheets were glued together to form a $10 \mathrm{~cm} \mathrm{(4}$

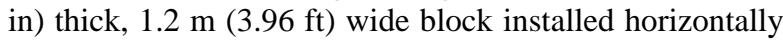
beneath the pavement.

5) Structural soil-a mixture of 2.5 parts gravel (2.5 to 3.75 $\mathrm{cm}$ [1 to $1.5 \mathrm{in}$ ] diameter) and one part clay loam soil was installed in a $10 \mathrm{~cm}$ (4 in) horizontal layer beneath the pavement.

6) No treatment control-concrete was poured directly on the soil surface as is typically done in this area for suburban sidewalks.

Nonreinforced concrete $\left(245 \mathrm{~kg} / \mathrm{cm}^{2}\right.$ [3,500 psi]) was poured to a depth of $10 \mathrm{~cm}$ ( $4 \mathrm{in}$ ) over the treatments and nontreated soil. The top of the concrete was nearly level with the adjacent soil. Concrete joints were scored at the beginning and end of each treatment and centered at each tree trunk. Treatments were $3 \mathrm{~m}$ (9.9 ft) long.

Steel reinforcement bars (rebar) $45 \mathrm{~cm}$ (18 in) long were driven into the soil at the base of each tree so the top of the rebar was even with the adjacent pavement. The height of the pavement was compared with the height of the adjacent rebar using a transit on 17 October 2005. The change in height of the concrete (lifting) was calculated by subtracting the initial concrete elevation to the final concrete elevation. A visual assessment of sidewalk cracking was also made on 17 January 2006. Cracks in the concrete were rated as either present or absent.

The sidewalk pavement was removed in October 2006 (Figure 2). Underlying soil and underpavement treatments were removed to a depth of $20 \mathrm{~cm}$ ( 8 in) below the bottom of the pavement using high-pressure water. Alongside-pavement treatments were left in place. Root measurements were collected in November and December 2006. Measurements included root depth, root diameter, and root surface area in contact with the pavement. Diameter and depth measurements were taken $15 \mathrm{~cm}$ (6 in) inside the edge of the pavement on both sides of the sidewalk. Depth was measured from the bottom of the pavement to the top of the root. Root diameter was measured perpendicular to the direction of the root growth axis at the same point as the root depth measurement. Root surface area in contact with the pavement was determined by measuring the length and width of the contact area as determined from photographs taken at the time of pavement removal and through visual examination of the roots. Roots with a diameter of $2.5 \mathrm{~mm}(0.1 \mathrm{in})$ or less were not measured. For the vertical treatments, a visual observation and counts were made of roots that grew over the top of the barriers.

Treatments were applied in a completely randomized design. Results were statistically analyzed using an analysis of variance and the Student-Newman-Keuls separation of means in SPSS (SPSS Inc., Chicago, IL) at the $P=0.05$ level.

\section{RESULTS}

There was a significant amount of sidewalk cracking at the scored joint adjacent to trees in four of five control treatments and three of five poly sheet and structural soil treatments. There were no significant differences in the amount of pavement lifting among treatments (Figure 3).

Treatments did affect root growth under the pavement. There were significantly fewer roots associated with the two vertical treatments (Figure 4). Those treatments also resulted in roots that were smaller in diameter (Figure 5) and deeper (Figure 6) than 


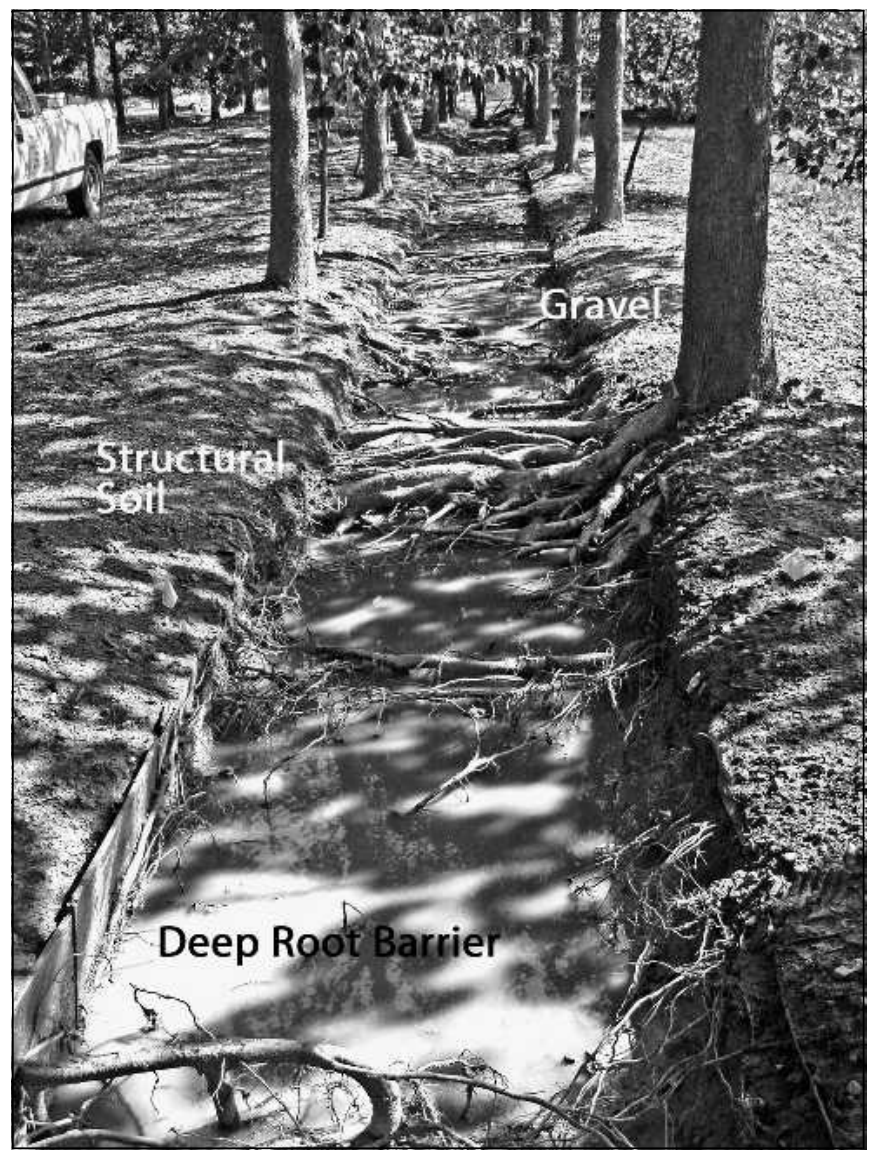

Figure 2. Root growth under pavement after sidewalk was removed.

the other treatments. Cracks that were associated with the poly sheet treatment were from roots that grew over the top of the barrier. Three of the five poly sheet treatments had large diameter (greater than $2.5 \mathrm{~cm}$ [1 in]) roots growing over the top of the barrier and beneath the pavement. None of the DeepRoot barrier treatments exhibited root overgrowth.

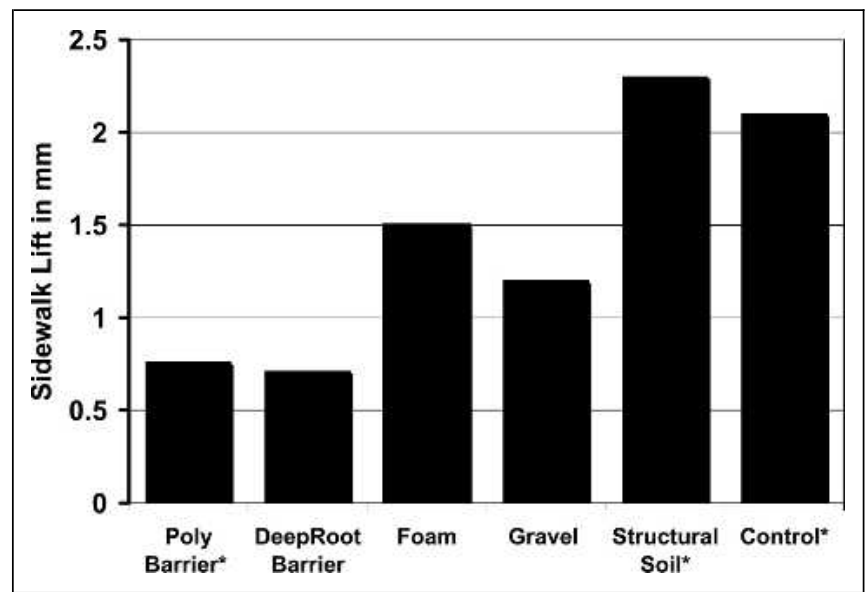

Figure 3. Sidewalk lifting directly adjacent to London plane trees caused by tree roots growing under pavement. Asterisked treatments indicate that root-related pavement cracking was present.

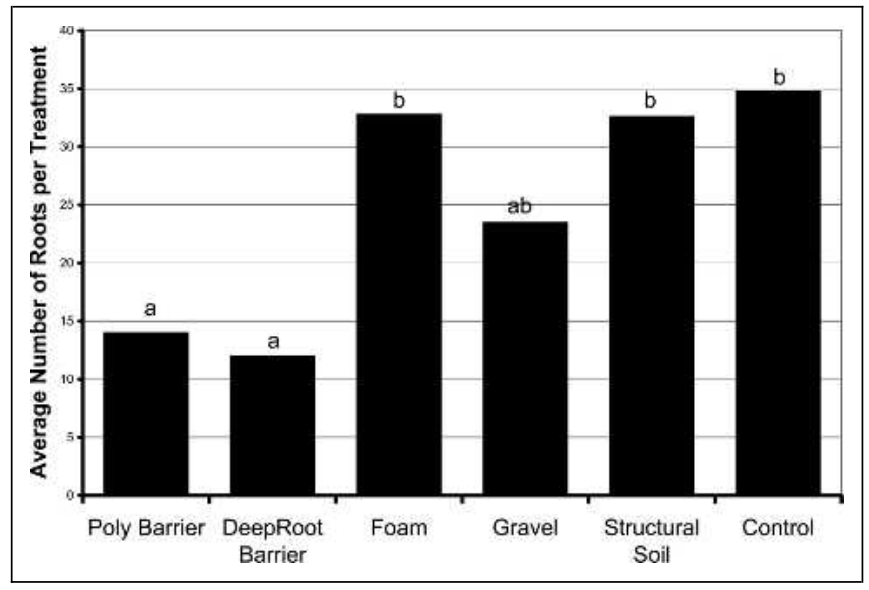

Figure 4. Average number of roots greater than $2.5 \mathrm{~mm}(0.1$ in) diameter found under the pavement of the different treatments to a depth of $20 \mathrm{~cm}$ (8 in). Treatments with the same letter on top of the bar were not significantly different.

The three treatments that exhibited cracking (control, structural soil, and poly sheet) also had the greatest root surface area contacting the pavement (Figure 7). It is likely that the upward force on the pavement was directly correlated to the root surface contact area.

Roots under the structural soil treatment had significantly larger diameters than other treatments (Figure 5). Contact area (Figure 7) was lower than expected for this treatment considering the greater amount of pavement lifting. The inconsistency was the result of a layer of gravel that separated the top of the roots from the bottom of the pavement. This kept the actual root contact area small but allowed the transfer of force through the gravel to the pavement. Pavement cracks associated with this treatment tended to be larger than those in other treatments.

Roots grew at deeper levels in the soil under the foam treatment (Figure 6) but were no greater in number or larger in diameter than the control. As the roots under the foam increased in diameter, they crushed the foam.

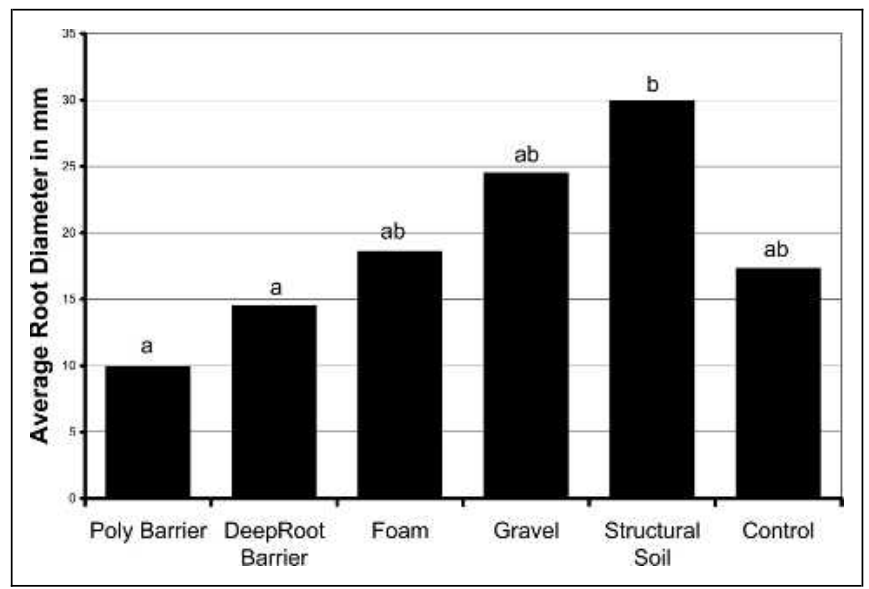

Figure 5. Average diameter of roots greater than $2.5 \mathrm{~mm}(0.1$ in) found under the pavement of different treatments to a depth of $20 \mathrm{~cm}$ (8 in). Treatments with the same letter on top of the bar were not significantly different. 


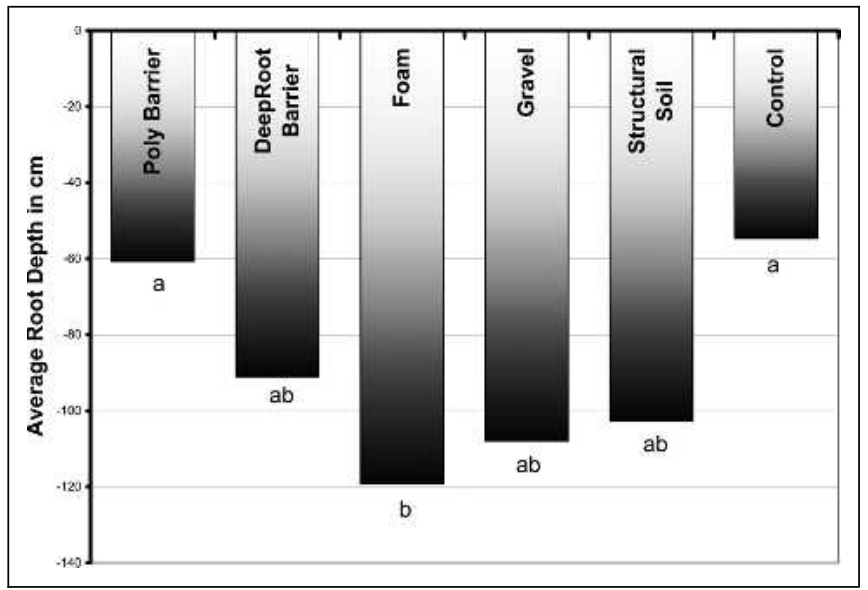

Figure 6. Average depth of roots greater than $2.5 \mathrm{~mm}(0.1 \mathrm{in})$ found under the pavement of specified treatments to a depth of $20 \mathrm{~cm}$ (8 in). Distance was measured from the bottom of the pavement to the top of the root. Treatments with the same letter were not significantly different.

Treatment had no significant effect on tree trunk diameter growth over the 10 years of study (Figure 8).

\section{DISCUSSION}

Alongside-pavement vertical barrier treatments were more effective at reducing root growth under pavement than underpavement treatments. This is very different than the results of Gilman (2006) who found little benefit from DeepRoot or poly sheet barriers. Differences between the two studies are most likely related to the root barrier depth $(30 \mathrm{~cm}$ [12 in] versus 45 $\mathrm{cm}$ [18 in] deep) and the texture of the soil (fine sand versus clay loam). Differences among types of root barriers have also been found several years after planting in this clay loam soil (Smiley 2005). Although the belowground effects of the two root barriers were very similar, the greatest difference between the DeepRoot and poly sheet barriers was the flexibility of the top edge. This edge of the poly sheet fell below the mulch or soil level at several points allowing roots to grow over the top, resulting in sidewalk cracking. The DeepRoot barrier prevented root over-

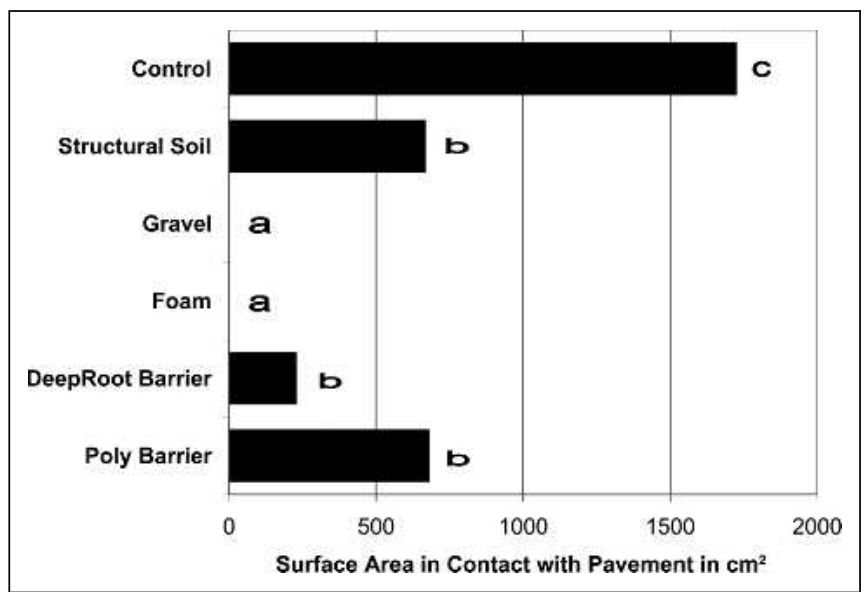

Figure 7. Total area of root contact with the bottom of the pavement. Treatments with the same letter were not significantly different.

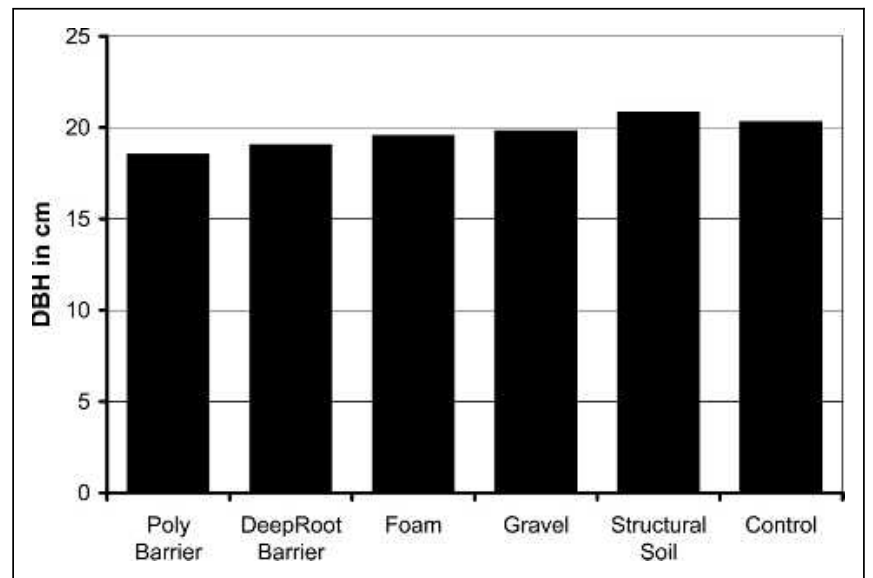

Figure 8. The effect of sidewalk treatment on tree diameter growth.

growth, although some of the panels settled after installation and the tops of those panels were below grade.

The foam treatment performed very well, especially in comparison to other underpavement treatments. The foam did not allow roots to grow in contact with the bottom of the pavement. Several roots did penetrate between sheets of foam, but these did not affect the pavement. As the roots under the foam increased in diameter, they crushed the foam, dispersing the upward force of root pressure.

Gravel has been used successfully as a base layer in The Netherlands (Kopinga 1994) and in Florida (Gilman 2006). Although gravel did work very well from a pavement protection perspective in this trial, it was only marginally effective at reducing root numbers, diameter of roots, or increasing root depth. A thicker layer of gravel may have been more effective in this moderately well-drained soil.

The use of structural soils in a layer only $10 \mathrm{~cm}$ (4 in) thick has never been recommended (Grabosky and Bassuk 1996). Typical installation depth is $60 \mathrm{~cm}$ (24 in). The $10 \mathrm{~cm}$ (4 in) thickness was used in this trial because structural soil has been seen in use at this depth under sidewalks, driveways, and garage floors. Roots grew well in the mixture achieving the largest root diameters of any treatment. However, this rapid root growth resulted in a large number of cracks in the pavement and the greatest amount of pavement lifting of any treatment.

The installation of treatments to reduce sidewalk damage at the time of sidewalk or tree installation is the preferred method of reducing sidewalk damage when tree species known to damage pavement are planted next to a sidewalk. This and other studies have found several treatments that will greatly reduce pavement damage. In this study on a moderately drained clay loam soil, the root barrier treatments were most effective. Foam or gravel installed beneath also worked very well by forcing root growth deeper in the soil. It is likely that the combination of vertical root barriers and underpavement treatments may reduce the risk of damage to pavement even further.

\section{LITERATURE CITED}

Barker, P.A., and P. Peper. 1995. Strategies to prevent damage to sidewalks by tree roots. Journal of Arboriculture 19:295-309.

Costello, L.R., C.L. Elmore, and S. Steinmaus. 1997. Tree root response to circling root barriers. Journal of Arboriculture 23:211-218. 
Costello, L.R., and K.S. Jones. 2003. Reducing infrastructure damage by tree roots: A compendium of strategies. International Society of Arboriculture, Cohasset, CA. 119 pp.

D'Amato, N.E., T.D. Sydnor, M. Knee, R. Hunt, and B. Bishop. 2002. Which comes first, the root or the crack? Journal of Arboriculture 28:277-289.

Gilman, E.F. 1996. Root barriers affect root distribution. Journal of Arboriculture 22:151-154.

2006. Deflecting roots near sidewalks. Arboriculture and Urban Forestry 32:18-22.

Grabosky, J., and N. Bassuk. 1996. Testing of structural urban tree soil materials for use under pavement to increase street tree rooting volumes. Journal of Arboriculture 21:197-201.

Kopinga, J. 1994. Aspect of the damage to asphalt road paving caused by tree roots. In Watson, G.W., and D. Neely (Eds.). The Landscape Below Ground. International Society of Arboriculture, Champaign IL.

McPherson, E.G. 2000. Expenditures associated with conflicts between street trees root growth and hardscape in California. Journal of Arboriculture 26:289-297.

McPherson, E.G., and P. Peper. 1995. Infrastructure repair costs associated with street trees in 15 cities. In Watson, G.W., and D. Neely (Eds.). Trees and Building Sites: Proceedings of an International Workshop on Trees and Buildings. International Society of Arboriculture, Champaign, IL.

Smiley, E.T. 2005. Root growth near vertical barriers. Journal of Arboriculture 31:150-152.

Smiley, E.T., L. Calfee, B.R. Fraedrich, and E.J. Smiley. 2006. Comparison of structural and noncompacted soils for trees surrounded by pavement. Arboriculture and Urban Forestry 32:164-169.

Smiley, E.T., A. Key, and C. Greco. 2000. Root barriers and windthrow potential. Journal of Arboriculture 26:213-217.

Wagar, J.A. 1985. Reducing surface rooting of trees with control planters and wells. Journal of Arboriculture 11:165-171.

Wagar, J.A., and P.A. Barker. 1983. Tree root damage to sidewalks and curbs. Journal of Arboriculture 9:177-181.

\section{E. Thomas Smiley}

Arboricultural Researcher

Bartlett Tree Research Laboratories

13768 Hamilton Road

Charlotte, NC 28278, U.S.

and

Adjunct Professor

Clemson University

Clemson, SC, U.S.

tsmiley@bartlettlab.com
Résumé. Les racines d'arbres qui poussent sous les trottoirs sont renommées pour fissurer ou soulever le pavage ce qui crée souvent des conditions hasardeuses pour les piétons. Cette expérience a été menée pour déterminer les effets à long terme de traitements sous et le long des trottoirs par rapport au développement du système racinaire et aux dommages causés au trottoir. Des platanes anglais (Platanus $\times$ acerifolia) ont été plantés à proximité de trottoirs au Laboratoire Bartlett de recherche sur les arbres à Charlotte en Caroline du Nord en 1996. Les traitements installés au moment de la plantation des arbres étaient une barrière universelle contre les racines d'arbres DeepRoot (UB18-2), une feuille verticale de polyéthylène, du gravier, un polystyrène extrudé Foamular $^{\circledR} 150$ et un sol structurant. Les trottoirs et le sol sous ces derniers ont été enlevés en 2006. Un soulèvement ou une fissuration minimal du trottoir ont été associés avec la barrière DeepRoot, le gravier et les panneaux de mousse. Les barrières verticales et les panneaux de mousse ont produit une quantité moindre de racines sous le pavé ainsi que des racines plus profondes. Les traitements n'ont eu aucun impact sur la croissance en diamètre des arbres.

Zusammenfassung. Baumwurzeln, die unter Gehwegen wachsen, können das Pflaster beschädigen oder anheben und damit eine Stolpergefahr für Fußgänger schaffen. Dieses Experiment wurde geleitet, um den Langzeiteffekt von Maßnahmen zur Wurzelentwicklung neben und unter dem Pflaster und den Schaden zu bestimmen. 1996 wurden am Bartlett Baumforschungslaboratorium in Charlotte, New York, Platanen neben einem Gehweg gepflanzt. Folgende Behandlungen wurden mit der Pflanzung installiert: DeepRoot Universal Tree Root Barrier (UB182), eine vertikale Polyethylen-Folie, Grobkies, Foamular ${ }^{\circledR} 150$ (Polystyren-Schaum) und strukturreicher Boden. In 2006 wurden die Gehwege und der Boden darunter entfernt. Bei der Wurzelbarriere, dem Kies und dem Schaum wurden nur minimale Bewegungen des Gehweges festgestellt. Vertikale Wurzelbarrieren und Schaum führten zu weniger und tieferen Wurzeln unter dem Pflaster. Die Behandlungen hatten keinen Einfluss auf den Stammdurchmesser.

Resumen. Se sabe que las raíces que crecen bajo las aceras con frecuencia rompen o levantan el pavimento creando un riesgo de tropiezo para los transeúntes. Este experimento se llevo a cabo para determinar los efectos a largo plazo de los tratamientos a lo largo y bajo los pavimentos, en el desarrollo de la raíz del árbol y el daño a las aceras. Se plantaron árboles de plátano (Platanus $\times$ acerifolia) cerca a aceras en el Bartlett Tree Research Lab en Charlotte, NC en 1996. Los tratamientos instalados en el momento de la plantación fueron: DeepRoot Universal Tree Root Barrier (UB18-2), lámina vertical de polietileno, grava, Foamular $^{\circledR} 150$ poliestireno espuma y un suelo estructural. Las aceras y el suelo debajo de ellos fueron removidos en 2006. Un levantamiento mínimo o rotura de aceras estuvo asociado con la barrera DeepRoot, grava y espuma. Las barreras verticales y la espuma resultaron en menos y más raíces profundas bajo el pavimento. Los tratamientos no impactaron el crecimiento del diámetro de los árboles. 